Vol II. No. 1, September 2017, hlm. 75 - 82

Available online at www.jurnal.una.ac.id/indeks/jmp

\title{
PERBEDAAN HASIL BELAJAR SISWA MELALUI METODE PENEMUAN TERBIMBING DENGAN DAN TANPA DISKUSI KELOMPOK
}

\author{
Sukamdi $^{1}$, Hidayat ${ }^{2}$ \\ Pendidikan Matematika, SMP Negeri 1 Meranti \\ Email: sukamdi@yahoo.co.id
}

\begin{abstract}
This study aims to determine differences in student learning outcomes in the learning of addition operations and reduction of fractions that apply guided discovery methods through group discussion with guided discovery methods without group discussion. The type of this research is experimental research with the design used is Randomized Control Group Pre Test - Post Test Design. The location of this research in SMA Negeri 1 Meranti. The sample used in this research consists of 2 classes, experimental class (VII 4) that is the class which is treated by guided discovery through group discussion, control class (VII - 5) that is class which apply method of discovery guided without group discussion. By using t-statistic test at significant level $(\alpha=0,05)$ in proving hypothesis obtained $\mathrm{t}$ Count $=4,675$ and $\mathrm{t}$ Table $=2,046$. This indicates that the $\mathrm{t}$ calculation price is within the rejection area of $\mathrm{H}_{\mathrm{o}}$ and accepts $\mathrm{H}_{\mathrm{a}}$ which states that there is a difference in student learning outcomes between the teaching that apply guided discovery method through group discussion with guided discovery method without group discussion on the addition operation and the reduction of the fraction in class VII SMP Negeri 1 Meranti.
\end{abstract}

Keywords: guided discovery, learning outcomes, fractional numbers

\begin{abstract}
Abstrak
Penelitian ini bertujuan untuk mengetahui perbedaan hasil belajar siswa pada pembelajaran operasi penjumlahan dan pengurangan bilangan pecahan yang menerapkan metode penemuan terbimbing melalui diskusi kelompok dengan metode penemuan terbimbing tanpa diskusi kelompok. Jenis penelitian ini adalah penelitian eksperimen dengan disain yang digunakan adalah Randomized Control Group Pre Tes - Pos Tes Design. Lokasi penelitian ini adalah SMP Negeri 1Meranti. Sampel yang digunakan dalam penelitian ini terdiri dari 2 kelas, kelas eksperimen ( VII - 4 ) yaitu kelas yang diberi perlakuan penemuan terbimbing melalui diskusi kelompok, kelas kontrol ( VII - 5 ) yaitu kelas yang menerapkan metode penemuan terbimbing tanpa diskusi kelompok. Dengan menggunakan uji statistik - t pada taraf signifikan $(\alpha=0,05)$ dalam pembuktian hipotesis diperoleh $t_{\text {Hitung }}=4,675$ dan $t_{\text {Tabel }}=2,046$. Ini menunjukkan bahwa harga $\mathrm{t}$ perhitungan berada dalam daerah penolakan $\mathrm{H}_{\mathrm{o}}$ dan menerima $\mathrm{H}_{\mathrm{a}}$ yang menyatakan bahwa ada perbedaan hasil belajar siswa antara pengajaran yang menerapkan metode penemuan terbimbing melalui diskusi kelompok dengan metode penemuan terbimbing tanpa diskusi kelompok pada operasi penjumlahan dan pengurangan bilangan pecahan di kelas VII SMP Negeri 1 Meranti.
\end{abstract}

Kata kunci :penemuan terbimbing, hasil belajar, bilangan pecahan 
Vol II. No. 1, September 2017, hlm. 75 - 82

Available online at www.jurnal.una.ac.id/indeks/jmp

Peningkatan ilmu dan relevansi pendidikan merupakan salah satu program pembangunan nasional dan sangat erat kaitannya dengan pengembangan Sumber Daya Manusia ( SDM ). Sistem pendidikan nasional menghadapi tantangan yang sangat kompleks dalam menyiapkan kualitas sumber daya manusia ( SDM ) yang mampu bersaing di era global. Upaya yang tepat untuk menyiapkan sumber daya manussia ( SDM ) yang berkualitas dan satu - satunya wadah yang dapat dipandang dan sesogianya berfungsi sebagai alat untuk membangun SDM yang bermutu tinggi adalah pendidikan.

Untuk mencapai pendidikan nasional pemerintah telah menyelenggarakan perbaikan perbaikan peningkatan mutu pendidikan pada berbagai jenis dan jenjang. Namun fakta di lapangan belum menunjukan hasil yang memuaskan. Maka upaya meningkatkan mutu pendidikan merupakan hal yang sangat penting. Seperti dikemukakan oleh Budi Raharjo ( 2003 : 3 )"Berbagai upaya dilakukan untuk meningkatkan mutu pendidikan nasional khususnya pendidikan dasar dan menengah pada setiap jenjang dan satuan pendidikan, antara lain dari berbagai pelatihan guru, perbaikan sarana dan prasarana pendidikan dan peningkatan mutu manajemen sekolah".Namun berbagai indikator menunjukan bahwa mutu pendidikan masih belum meningkat secara signifikan.

Salah satu indikator rendahnya mutu pendidikan adalah hasil belajar siswa yang rendah.Rendahnya hasil belajar siswa diantaranya disebabkan oleh pembelajaran yang dilakukan guru. Hasil belajar siswa yang rendah juga terjadi pada mata pelajaran matematika. Dalam pelajaran matematika di sekolah dasar materi pecahan dan operasinya sudah diajarkan akan tetapi berdasarkan hasil wawancara peneliti dengan salah seorang guru yang mengajar di SMP Negeri 1 Meranti. ( informasi: Sumar, S.Pd, 10 November 2015 ) mengatakan: " Kemampuan siswa dalam menyelesaikan operasi bilangan pecahan masih mengalami kesulitan ".

. Hal ini disebabkan metode yang digunakan belum sesuai masih bersifat konvensional, sehingga siswa kurang aktif dalam proses belajar, hal ini sangat mempengaruhi hasil belajar siswa dalam bidang matematika, khususnya dalam materi operasi pecahan.

Ada banyak faktor yang dapat mempengaruhi hasil belajar siswa, baik faktor eksternal maupun internal.Faktor - faktor non sosial dapat dikatakan tidak terbilang banyak jumlahnya seperti kondisi sekolah dan sarana prasarana sekolah. Hal tersebut harus diatur sedemikian rupa, diusahakan agar dapat memenuhi syarat - syarat menurut pertimbangan, psikologi dan paedagogis.

Faktor - faktor sosial ini adalah faktor hubungan antara guru dengan siswa dan hubungan antara siswa dengan siswa. Ketidakharmonisan mereka sangat mempengaruhi siswa dalam belajar. Hal ini perlu diatur agar dapat berlangsung sebaik - baiknya.

Faktor - faktor psikologis, pada faktor ini harus ditinjau, sebab terjadi yang melatar belakangi aktivitas belajar. Misalnya :

Intelegensi, pada umumnya dapat diartikan sebagai psikofisik untuk mereaksi rangsangan atau menyesuaikan diri dengan 
Vol II. No. 1, September 2017, hlm. 75 - 82

Available online at www.jurnal.una.ac.id/indeks/jmp

lingkungannya secara tepat. Setiap siswa mempunyai tingkat intelegensi yang berbeda - beda oleh karena itu harus di asa agar dapat mencapai tingkat yang diinginkan.

Sikap adalah gejala atau yang berdimensi efektif berapa kecendrungan untuk mereaksi respon dengan cara yang relatif tetap terhadap objek orang, barang, dan sebagainya baik secara positif maupun negatif.Oleh karena siswa harus bisa menjaga sikapnya dengan baik.

Minat dapat mempengaruhi kualitas hasil belajar dalam studi hasil belajar tertentu. Karena apabila siswa tidak minat dengan suatu pelajaran tertentu maka hasilnya akan kurang maksimal.

Motivasi, motivasi mencapai hasil dan motivasi memeliki pengetahuan dan keterampilan untuk masa depan, memberi pengaruh lebih kuat dan relatif lebih terjaga dibandingkan dengan motivasi hadiah atau motivikasi keharusan dari orang tua dan guru. Di dalam ini orang tua dan guru harus memberi motivasi agar anak / siswa dapat termotivasi untuk belajar, guna untuk mencapai kesuksesan anak tersebut.

Hal di atas sangat berpengaruh dalam belajar siswa. Apalagi pembelajaran difokuskan tingkat hapalan sehingga siswa banyak mengalami kesulitan. Kurangnya penguasaan konsep dengan benar mengakibatkan siwa tidak mengembangkan konsep yang dimiliki, sehingga siswa cendrung menghapal langkah - langkah penyelesaian yang diberikan secara konvensional.

\section{METODE}

Penelitian ini dilaksanakan di SMP Negeri 1 Meranti jln. Karya No : 95 Meranti. Sekolah ini dijadikan lokasi penelitian karena peneliti mengadakan pra penelitian untuk menanyakan masalah - masalah yang di hadapi siswa dalam pembelajaran khususnya mata pelajaran matematika.

Populasi dalam penelitian ini adalah seluruh siswa kelas VII SMP Negeri 1 Meranti tahun pelajaran 2014/2015 yang terdiri dari 6 kelas.

Pengambilan sampel dalam penelitian ini diambil secara acak sebanyak 2 kelas dari ( kelas VII-4 dan kelas VII-5 ) dari 6 kelas ( Kelas VII-1 s/d VII-6 ). Kemudian dari 2 kelas yang terpilih secara acak dipilih kelas VII-4 sebagai kelas eksperimen yang terdiri dari 32 siswa ( 12 Laki - laki dan 20 Perempuan ) dan kelas VII-5 sebagai kelas kontrol yang terdiri atas 32 siswa ( 15 Laki - laki dan 17 Perempuan ). Pengambilan sampel secara acak dilakukan karena setiap kelas memiliki karakteristik yang sama yang ditinjau dari hasil tujuan penerimaan siswa baru.

Dalam penelitian eksperimen terdapat beberapa variabel. Adapun yang menjadi variabel dalam penelitian ini adalah hasil belajar siswa pada materi pecahan, aljabar dan perbandingan, sebagai variabel terikat. Sedangkan sebagai variabel bebas adalah pembelajaran dengan menerapkan metode penemuan terbimbing melalui diskusi kelompok dan penemuan terbimbing tanpa diskusi kelompok.

Penelitian ini dikatagorikan kedalam penelitian eksperimen yaitu membandingkan satu kelompok eksperimen yang diberi perlakuan yaitu 
Vol II. No. 1, September 2017, hlm. 75 - 82

Available online at www.jurnal.una.ac.id/indeks/jmp

pembelajaran dengan metode penemuan terbimbing melalui diskusi kelompok dengan satu kelompok kontrol yang menerapkan pembelajaran dengan metode penemuan terbimbing tanpa diskusi kelompok. Dalam hal ini eksperimen yang dilakukan adalah eksperimen tentang perbedaan hasil belajar siswa yang menerapkan metode penemuen terbimbing melalui diskusi kelompok dengan metode metode penemuan terbimbing tanpa diskusi kelompok di SMP Negeri 1 Meranti.

Disain yang akan digunakan dalam penelitian ini adalah Randomized Control Group Pre Tes Pos Tes Desaign seperti digambarkan dibawah ini.

Hasil Pretes dan Postes diperiksa sebagai data hasil belajar siswa. Data yang terkumpul berupa data sekor yang diperoleh dari hasil tes yaitu Pretes dan Postes yang berjumlah 10 butir soal. Soal yng diberikan berbentuk essay dengan soal, kunci jawaban, pedoman pensekoran, hasil Pretes dan Postes dan selisih Pretes dan Postes terlampir.

Sebelum tes diujikan pada kelas penelitian, terlebih dahulu tes dianalisis apakah tes layak untuk diujikan. Untuk mengetahui apakah tes layak uji dilihat validitas dan reabilitas dari tes itu. Untuk itu tes diuji cobakan di luar sampel dan diperoleh karakteristik soal. Dengan

Kelompok Pretes Treatmen Postes menggunakan rumus Product Moment \begin{tabular}{cccc} 
& $\mathbf{t}$ & diperoleh validitas setiap butir soal dari \\
\hline & $\mathrm{X}_{1}$ & $\mathrm{~T}_{2 \mathrm{r}}$
\end{tabular}

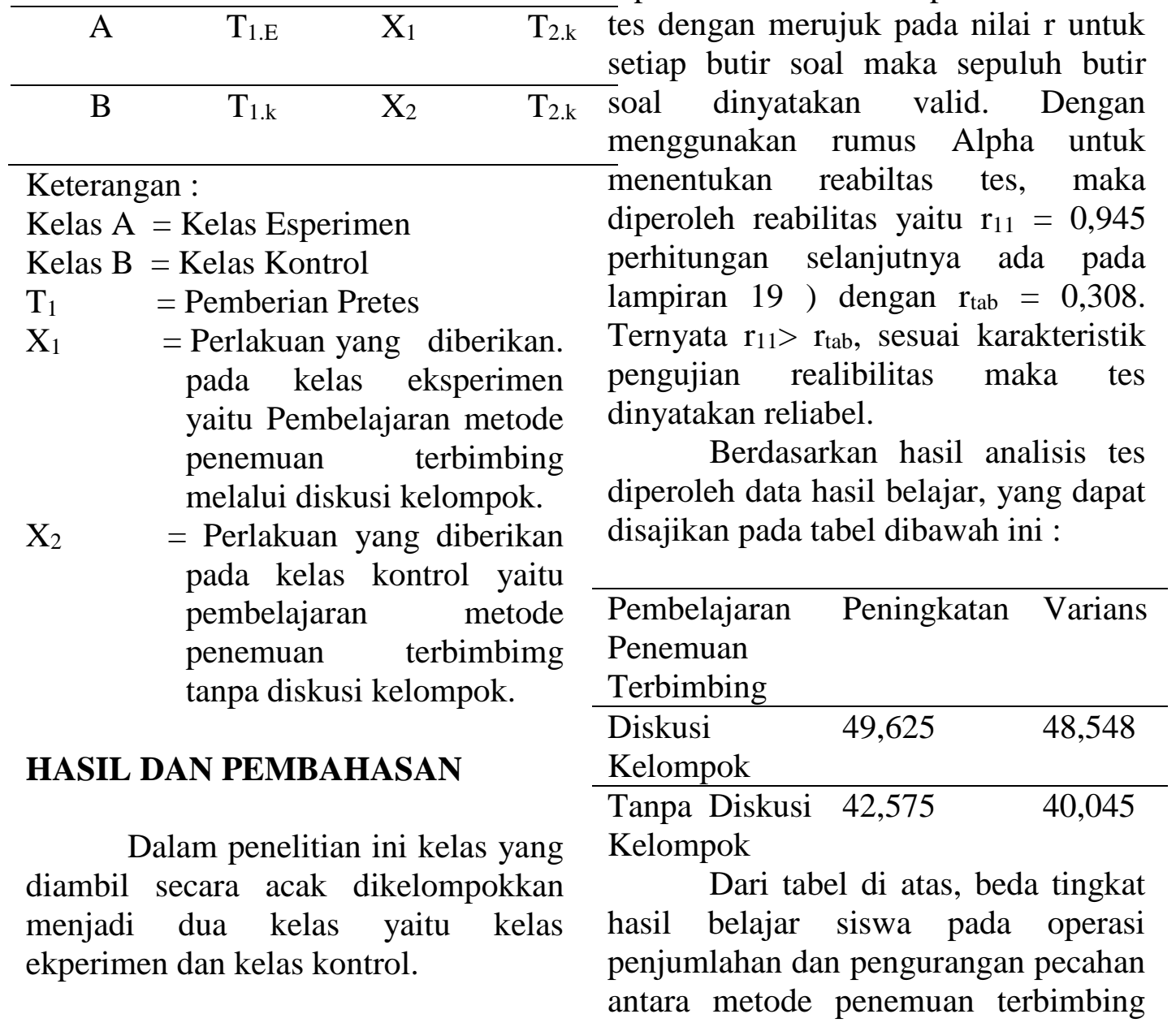


Vol II. No. 1, September 2017, hlm. 75 - 82

Available online at www.jurnal.una.ac.id/indeks/jmp

melalui diskusi kelompok dengan metode penemuan terbimbing tanpa diskusi kelompok adalah 49,625 $42,575=7,05$ atau tidak sama dengan nol, karena beda tingkat hasil belajar siswa dalam menyelesaikan operasi penjumlahan dan pengurangan pecahan antara metode penemuan terbimbing melalui diskusi kelompok dengan metode penemuan terbimbing tanpa diskusi kelompok sebesar 7,05, ini berarti ada perbedaan antara hasil belajar siswa dengan metode penemuan terbimbing dengan dan tanpa diskusi kelompok.

1. Uji Normalitas Data

Dari hasil perhitungan uji normalitas pada kelas eksperimen diperoleh $\chi^{2}$ hit $=8,2013$ dan pada kelas kontrol diperoleh $\chi^{2}$ hit $=7,4708 \quad($ perhitungan selengkapnya pada lampiran 23 ). Berdasarkan tabel distribusi Chi-kuadrat untuk $\mathrm{dk}=\mathrm{k}-1$ $=6$ dan $\alpha=0,05$ diperoleh $\chi_{\text {tabel }}^{2}=$ 12,6. Ternyata pada kedua kelas sampel $\chi^{2}$ tabel $>\chi^{2}$ hit. Menurut kriteria pengujian normalitas data pada Bab III disimpulkan bahwa terima $\mathrm{H}_{0}$ yang menyatakan data peningkatan hasil belajar pada operasi penjumlahan dan pengurangan pecahan dengan metode penemuan terbimbing melalui diskusi kelompok maupun metode penemuan terbimbing tanpa diskusi kelompok adalah berdistribusi normal.

2. Uji Homogenitas Varians Kedua Kelas

Sebelum dilakukan uji hipotesis, terlebih dahulu diuji homogenitas varians dan peningkatan hasil belajar siswa dalam menyelesaikan soal operasi penjumlahan dan pengurangan pecahan dari kedua kelas sampel karena berkaitan dengan rumus $\mathrm{t}$ yang akan digunakan.
Dari hasil perhitungan pada lampiran 24, diperoleh $\mathrm{F}_{\text {hit }}=1,212$. Berdasarkan tabel $\mathrm{F}$ untuk $\mathrm{dk}$ pembilang $=39 \mathrm{dk}$ penyebut $=39$ serta $\alpha=0,05$ diperoleh $\mathrm{F}_{(0,05 ; 39 ; 39)}=\mathrm{F}_{\mathrm{tab}}=$ 1,705. Ternyata $F_{\text {hit }}<F_{\text {tab. }}$. Berdasarkan kriteria pengujian homogenitas varians kedua kelas sampel pada Bab III disimpulkan bahwa kedua data tingkat perubahan hasil belajar siswa dalam menyelesaikan soal operasi penjumlahan dan pengurangan pecahan memiliki varians yang homogen.

Dari hasil uji persyaratan di atas diketahui data tingkat hasil belajar siswa dalam menyelesaikan soal opererasi penjumlahan dan pengurangan pecahan kedua kelas berdistribusi normal dan memiliki varians yang homogen, sehingga untuk menguji apakah ada perbedaan hasil belajar siswa antara pengajaran yang menerapkan metode penemuan terbimbing melalui diskusi kelompok dengan metode penemuan terbimbing tanpa diskusi kelompok dlam menyelesaikan soal operasi penjumlahan dan pengurangan pechan digunakan statistik t. Berdasarkan hasil perhitungan pada lampiran 25 diperoleh $t_{\text {hit }}=4,675$ dan setelah dikonsultasikan terhadap tabel distribusi tuntuk $\alpha=0,05$ dan $\mathrm{dk}=78$ diperoleh $t_{\text {tab }}=2,046$. Ternyata 4,675 tidak terletak antara -2,046 dan 2,046. Maka kriteria pengujian hipotesis adalah menolak $\mathrm{H}_{\mathrm{o}}$ dan menerima $\mathrm{H}_{\mathrm{a}}$ yang menyatakan adanya perbedaan hasil belajar siswa antara pengajaran yang menerapkan metode penemuan terbimbing melalui diskusi kelompok dengan metode penemuan terbimbing tanpa diskusi kelompok pada operasi penjumlahan dan pengurangan pecahan di kelas VII SMP Negeri 1 Meranti. 
Vol II. No. 1, September 2017, hlm. 75 - 82

Available online at www.jurnal.una.ac.id/indeks/jmp

$\begin{array}{llll}\text { Berdasarkan } & \text { perhitungan } & \text { lampiran } 27 \text { dan merujuk pada kriteria } \\ \text { ketuntasan belajar siswa kelas } & \text { ketuntasan diperoleh data sebagai } \\ \text { eksperimen pada lampiran } 26 \text { dan } & \text { berikut: }\end{array}$
ketuntasan belajar kelas kontrol pada

\begin{tabular}{|c|c|c|c|}
\hline $\begin{array}{c}\text { Pembelajaran } \\
\text { Penemuan Terbimbing }\end{array}$ & $\begin{array}{c}\text { Tuntas } \\
\text { Individual }\end{array}$ & $\begin{array}{l}\text { Persentase } \\
\text { Ketuntasan }\end{array}$ & $\begin{array}{c}\text { Ketuntasan } \\
\text { Klasikal }\end{array}$ \\
\hline Diskusi Kelompok & & & \\
\hline Tanpa Diskusi Kelompok & 27 Orang & $67,5 \%$ & Tidak Tuntas \\
\hline $\begin{array}{l}\text { Dari tabel dapat dilihat } \\
\text { bahwa tingkat keberhasilan siswa } \\
\text { dalam menyelesaikan soal operasi } \\
\text { penjumlahan dan pengurangan pecahan } \\
\text { dengan metode penemuan terbimbing } \\
\text { melalui diskusi kelompok secara } \\
\text { individual mencapai } 34 \text { orang siswa } \\
\text { dinyatakan tuntas belajar atau tingkat } \\
\text { keberhasilan secara klasikal 85\%. } \\
\text { Berdasarkan kriteria ketuntasan belajar }\end{array}$ & \multicolumn{3}{|c|}{$\begin{array}{l}\text { 42,575. Selisih rata - rata hasil belajar } \\
\text { siswa dalam operasi penjumlahan dan } \\
\text { pengurangan pecahan antara kelas } \\
\text { eksperimen dengan kelas kontrol } \\
\text { adalah } 7,05 \text {, ini berarti ada perbedaan } \\
\text { hasil belajar siswa antara pengajaran } \\
\text { yang menerapkan metode penemuan } \\
\text { terbimbing melalui diskusi kelompok } \\
\text { dengan penemuan terbimbing tanpa } \\
\text { diskusi kelompok. }\end{array}$} \\
\hline
\end{tabular}
bahwa metode penemuan terbimbing melalui diskusi kelompok memenuhi kriteria ketuntasan belajar siswa. Pada metode penemuan terbimbing tanpa diskusi kelompok, siswa yang mencapai ketuntasan belajar sebanyak 27 orang siswa atau tingkat keberhasilan secara klasikal 67,5\% hal ini dapat disimpulkan bahwa metode penemuan terbimbing tanpa diskusi kelompok belum memenuhi kriteria ketuntasan belajar siswa.

Selisih postes dan pretes pada kelas eksperimen adalah 49,625. Hal ini menunjukan peningkatan hasil belajar siswa pada operasi penjumlahan dan pengurangan pecahan dengan metode penemuan terbimbing melalui diskusi kelompok rata - rata 49,625. Pada kelas kontrol selisih pretes dan postes adalah 42,575. Hal ini menunjukan bahwa peningkatan hasil belajar pada operasi penjumlahan dan pengurangan pecahan dengan metode penemuan terbimbing tanpa diskusi kelompok dalam pelajaran rata - rata siswa pada kelas eksperimen lebih besar dari pada kelas kontrol dan dari hasil pengujian hipotesis dapat disimpulkan bahwa adanya perbedaan hasil belajar siswa antara pengajaran yang menerapkan metode penemuan terbimbing melalui diskusi kelompok dengan metode penemuan terbimbing tanpa diskusi kelompok. Hal ini menunjukkan bahwa pembelajaran dengan metode penemuan terbimbing melalui diskusi kelompok lebih cepat digunakan untuk meningkatkan hasil belajar siswa pada materi operasi penjumlahan dan pengurangan pecahan.

Pada pembelajaran yang menerapkan metode penemuan terbimbing melalui diskusi kelompok siswa yang mencapai tuntas belajar $85 \%$ berdasarkan ketuntasan belajar siswa, metode penemuan terbimbing melalui diskusi kelompok ini tuntas secara klasikal. Sedangkan metode penemuan terbimbing tanpa diskusi kelompok siswa yang mencapai tuntas 
Vol II. No. 1, September 2017, hlm. 75 - 82

Available online at www.jurnal.una.ac.id/indeks/jmp

belajar 67,5\%, hal ini berarti tidak tuntas secara klasikal. Hal ini menunjukkan pembelajaran penemuan terbimbing melelui diskusi kelompok lebih baik untuk meningkatkan ketuntasan belajar siswa.

\section{SIMPULAN}

1. Ada perbedaan hasil belajar siswa antara pengajaran yang menerapkan metode penemuan terbimbing melalui diskusi kelompok dengan metode penemuan terbimbing tanpa diskusi kelompok.

2. Pembelajaran dengan metode penemuan terbimbing melalui diskusi kelompok mencapai ketuntasan belajar secara klasikal pada operasi penjumlahan dan pengurangan pecahan sedangkan metode penemuan terbimbing tanpa diskusi kelompok tidak mencapai ketuntasan belajar secara klasikal pada operasi penjumlahan dan pengurangan pecahan.

\section{Saran}

1. Guru sebaiknya memilih metode penemuan terbimbing melalui diskusi kelompok ketika melakukan pembelajaran pada materi pecahan.

2. Pembelajaran dengan penerapan metode penemuan terbimbing

\section{DAFTAR RUJUKAN}

Arikunto, Suharsini. 2005. Dasar Dasar Evaluasi Pendidikan. Jakarta : Bumi Aksara

Azhar. 1993. Proses Belajar Mengajar Pola CBSA. Surabaya : Usaha Nasional melalui diskusi kelompok sangat baik dilakukan pada siswa yang aktif. Untuk siswa yang kurang aktifpenemuan terbimbing melalui diskusi kelompok dapat dilakukan jika guru dapat mengelompokkan siswa secara benar dan guru memiliki kemampuan dalam memotivasi siswa untuk berperan aktif dalam berdiskusi.

3. Pada pembelajaran dengan penerapan metode penemuan terbimbing melalui diskusi kelompok guru merupakan fasilisator yang mampu mengarahkan pembelajaran benar benar bermakna, agar ini dapat tercapai hendaknya guru menguasai metode penemuan terbimbing itu sendiri, menguasai materi, menguasai bahan, memahami psikologi siswa dan mampu menguasai cara pengelompokkan diskusi kelompok.

4. Bagi peneliti yang akan melakukan tentang metode penemuan terbimbing hendaknya dikembangkan melalui teknik yang lain misalnya : melalui latihan (drill), penugasan peroyek atau dengan melalui tutor sebaya.

Ruseffendi E.T. 1980. Pengantar Kepada Membantu Guru Mengembengkan

Kompetensinya Dalam Pengajaran Matematika Untuk Meningkatkan CBSA. Bandung : Tarsito 


\section{Gurnal \\ MATEMATICS PAEDAGOGIC}

Vol II. No. 1, September 2017, hlm. 75 - 82

Available online at www.jurnal.una.ac.id/indeks/jmp

Sudjana, Nana. 2006. Peneilaian

Proses Hasil Belajar

Mengajar. Bandung : Remaja

Rosda Karya.

Sukmawati, 2012. Evaluasi Proses

Dan Hasil Pembelajaran

Matematika 
Vol II. No. 1, September 2017, hlm. 75 - 82

Available online at www.jurnal.una.ac.id/indeks/jmp 